Takeshi Kanda (1), Hajime Hirase (1) ((1) RIKEN Brain Science Institute)

The brain is a highly energy-demanding organ in spite of its relatively small mass However, it is still unclear how the energy is consumed. The intracellular concentration of potassium is relatively high and that of sodium is low at rest in neurons. Although the ionic flux during a single action potential is extremely small, prolonged repetitive firing causes imbalance of the resting ionic composition, resulting in inability to discharge action potentials. To maintain precise and long-term firing, ion pumps operate to restore the ionic imbalance with the energy supplied by ATP, which is predicted to be the energetically most costly process by a model study. Thus, it is hypothesized that the high frequency firing requires a large amount of energy supply. To test the hypothesis, we examined if ATP production capability depend on the firing rates of cerebellar neurons using in vivo juxtacellular recording and immunocytochemical techniques. Purkinje cells spontaneously fired at a high rate, whereas firing of granule cells was sparse and irregular. Immunohistochemical staining of ATP synthase, a key enzyme for ATP production, revealed the expression levels were higher in the molecular and Purkinje cell layer than granule cell layer. The difference of firing activity between cell types correlated positively to their ATP synthase expression levels. Our results suggest that the energy production capabilities depend on the neuronal firing rates.

\section{P-190 グルタミン酸トランスポーターによる軟体動物腹足類の咀嚼リズ} ム形成の制御

Roles of glutamate transport systems in feeding rhythm generation of pond snails

Dai Hatakeyama (1), Koichi Mita (1), Suguru Kobayashi (1), Hisayo Sadamoto (1), Etsuro Ito (1) ((1) Tokushima Bunri University)

Previous studies for glutamate and its receptors suggested that glutamate is used as a neurotransmitter in generation of feeding rhythm in the pond snail Lymnaea stagnalis. The uptake mechanism of glutamate, however, is not yet known in Lymnaea, and thus in the present study we characterized glutamate transporters and examined their functions in the feeding circuits of the central nervous system (CNS) in Lymnaea. First, measurement of the accumulation of $3 \mathrm{H}$-labeled glutamate showed the presence of glutamate transport systems with different types of glutamate transporters, excitatory amino acid transporter (EAAT) and vesicular glutamate transporter (VGluT), in the Lymnaea CNS. The highest accumulation rate was obtained in the buccal ganglia, suggesting the involvemen of glutamate transport systems in the feeding behavior. Second, 2 types of glutamate transporters cloned from the Lymnaea CNS, LymEAAT and LymVGluT, were well conserved in their functional domains in comparison of the amino acid sequences with those of mammalian isoforms. Third, in-situ hybridization showed that the mRNAs of LymEAAT and LymVGluT were localized in the major feeding motoneurons in the buccal ganglia. Finally, the changes in firing patterns of the feeding motoneurons, which have glutamatergic inputs, by inhibition of LymEAAT were similar to those by stimulating with glutamate. Our results evidenced the presence of glutamate uptake systems in the Lymnaea CNS, and showed that they are required for proper generation for feeding rhythm in Lymnaea.

\section{P-191ストレスホルモンが後シナプスに及ぼす急性効果}

Rapid morphological changes of postsynapses induced by stress hormone in rat hippocampus

Yoshimasa Komatsuzaki (1), Masatoshi Kasuya (2), Yasushi Hojo (2), Suguru Kawato (2) ((1) Nihon Univ; Univ of Tokyo: (2) Univ of Tokyo; JST Bioinformatics)

Modulation of hippocampal synaptic plasticity by corticosterone (CORT, stress hormone) has been attracting much attention. The level of circulating CORT is increased to $1 \mu \mathrm{M}$ due upon stress responses. Spines (postsynapses) are essential for memory storage processes. We demonstrated the rapid effect of CORT on the density and morphology of spines by imaging Lucifer Yellow-injected neurons in adult male rat hippocampal slices. The application of $1 \mu \mathrm{M}$ CORT induced a rapid increase in the density of spines of pyramidal neurons within $1 \mathrm{~h}$. CORT selectively increased the density of large-head spines, however no significant change was observed for small-head spines.

From inhibitor experiments, we conclude that the signaling pathway involve receptor of CORT (GR) in spine $\rightarrow$ MAP kinase in spine $\rightarrow$ spine remodeling (increase in the density of large-head spines). These rapid events by CORT are non-genomic and not mediated via slow $(>6 \mathrm{~h})$ genetic processes mediated via GR moving to nuclei. These results suggest that exposure to acute stress $(\sim 1 \mathrm{~h})$ may activate hippocampal neurons.

\section{P-192 末梢神経損傷後に脊髄で増加するP2Y 受容体}

Induction of P2Y receptors in the spinal cord following peripheral nerve injury.

Kimiko Kobayashi (1), Hiroki Yamanaka (1), Koichi Noguchi (1) ((I) Department of Anatomy and Neuroscience, Hyogo College of Medicine)
Nerve injury often leads to neuropathic pain, such as thermal hyperalgesia and mechanical allodynia, painful responses to normally innocuous stimuli. Microglia in the spinal cord may play an important role in the development and maintenance of neuropathic pain. A prominent signaling pathway in the development of neuropathic pain involves ATP acting on microglial purinergic receptors. The rat $\mathrm{P} 2 \mathrm{Y}$ receptor family have been cloned that exhibit sensitivity to the ATP/ADP (P2Y1, 12, 13), UTP/UDP (P2Y2, 4, 6), UDP-glucose (P2Y14) or both adenine and uracil nucleotides (P2Y2). In this study, we examined expression of other $\mathrm{P} 2 \mathrm{Y}$ receptors in the spinal cord of neuropathic pain model rat and investigated whether other $\mathrm{P} 2 \mathrm{Y}$ receptors are involved in the pathogenesis of neuropathic pain following peripheral nerve injury.

Using spared nerve injury (SNI) model rat, we investigated the expression of $\mathrm{P} 2 \mathrm{Y}$ receptors mRNA in spinal cord. RT-PCR revealed that P2Y6, 12, 13 and 14 receptors mRNA showed the increase following SNI and peaked at 3 day after injury. Next, we examined the specific expression pattern of these receptors and their changes after SNI in the rat spinal cord using in situ hybridization histochemistry. Following SNI, P2Y6, 12, 13 and 14 mRNA increased strikingly in the ipsilateral dorsal horn. Combined ISHH with immunohistochemistry for NeuN, GFAP, or Iba1 revealed that these receptor mRNAs were seen only over the Iba1-ir cells in the ipsilateral dorsal horn after nerve injury.

Our data suggest that the ATP and other nucleotides may modulate an activated microglia considering the upregulation $\mathrm{P} 2 \mathrm{Y}$ receptors following nerve injury.

\section{P-193 カエル神経筋接合部シナプスにおける $\mathrm{Mg}^{2+}$ を含んだ $\mathrm{Ca}^{2+}$ フリー 溶液中での連続刺激による自発放出頻度增大現象の主要因は $\mathrm{Ca}^{2+}$ チャネルを通じてのシナプス前末端内への $\mathrm{Mg}^{2+}$ 蓄積である} Accumulation of $\mathrm{Mg}^{2+}$ in the frog motor nerve terminals through $\mathrm{N}$ type $\mathrm{Ca}^{2+}$ channels causes stimulation-induced enhancement of MEPP frequency under $\mathrm{Ca}^{2+}$-free $\mathrm{Mg}^{2+}$-containing condition

Naoya Suzuki (1) ((1) Nagoya University, School of Science, Department of Physics)

Effects of $\mathrm{Ca}^{2+}$ and $\mathrm{Mg}^{2+}$ on tetanic and post-tetanic enhancement of miniature end-plate potential (MEPP) frequency was examined at the frog neuromuscular junction using conventional electrophysiological techniques and imaging techniques with ion sensitive fluorescent dyes loaded in presynaptic terminals. About thirty times enhancement of MEPP frequency was induced by $100 \mathrm{~Hz}$ tetanus for $50 \mathrm{sec}$ in an EGTA-chelated $\mathrm{Ca}^{2+}$-free $\mathrm{Mg}^{2+}$ containing external solution. $\mathrm{Ca}^{2+}$-imaging indicated that there was no increase in $\left[\mathrm{Ca}^{2+}\right]_{\mathrm{i}}$ at the presynaptic terminals during tetanus in this condition. This result indicates that this enhancement of MEPP frequency did not accompany an increase in $\left[\mathrm{Ca}^{2+}\right]_{\text {. }}$ When the external concentration of $\mathrm{Mg}^{2+}$ was decreased from $5 \mathrm{mM}$ to $2 \mathrm{mM}$, peak value of the tetanus-induced enhancement of MEPP frequency was reduced to about a half. Blocking of $\mathrm{N}$-type $\mathrm{Ca}^{2+}$ channels with the application of $2 \mu \mathrm{M}$ $\omega$-conotoxin GVIA reduced the peak value of the enhancement of MEPP frequency to about $30 \%$ of that before the application of GVIA. When the concentration of $\omega$-conotoxin GVIA was raised to $8 \mu \mathrm{M}$, enhancement peak was reduced to about $25 \%$ of that before the application of GVIA. $\mathrm{Mg}^{2+}$-imaging indicated that $\left[\mathrm{Mg}^{2+}\right]_{\mathrm{i}}$ in the terminals increased to about 1.5 times of its resting level during tetanus. This tetanus-induced increase in $\left[\mathrm{Mg}^{2+}\right]_{\mathrm{i}}$ was reduced to about half and one-third when $\mathrm{Ca}^{2+}$ channels were blocked with 2 and $8 \mu \mathrm{M}$ of $\omega$-conotoxin GVIA, respectively. These results suggest that $\mathrm{Mg}^{2+}$ enters presynaptic terminals during action potentials through $\mathrm{N}$-type $\mathrm{Ca}^{2+}$ channels, and that $\mathrm{Mg}^{2+}$ accumulation in the presynaptic terminals is the main cause of the tetanus-induced enhancement of MEPP frequency in the EGTA-chelated $\mathrm{Ca}^{2+}$ free $\mathrm{Mg}^{2+}$ containing external solution.

\section{P-194 ナメクジ嗅覚中枢における FMRFamide 陽性ニューロンの役割}

The role of FMRFamidergic neurons in the olfactory center of Limax

Mariko Hattori (1), Suguru Kobayashi (1), Ryota Matsuo (1), Etsuro Ito (1) ((1) Kagawa School of Pharmaceutical Sciences, Tokushima Bunri University)

The terrestrial slug Limax has a well developed olfactory system. The main target of olfactory projection from the tentacles is the pocerebrum (PC). On the surface of the PC, synchronized oscillatory activity of neurons is recorded as a local field potential (LFP), and its oscillatory activity is involved in the odor information processing. Recently, we found that Phe-Met-Arg-Phe-NH2 (FMRFamide)immunopositive neurons are located in the PC. We thus here investigated the effects of FMRFamide on the LFP oscillation. Application of FMRFamide decreased the frequency of the LFP in a dose-dependent manner. Application of N-ethylmaleimde (NEM), a pertussis toxin-sensitive $\mathrm{Gi}$ inhibitor, blocked the effects of FMRFamide, whereas application of amiloride, an ionotropic receptor antagonist of FMRFamide, had no effect. These results suggest that the metabotropic receptors are involved in the decrease of LFP. There are two electrophysiologically different classes of neurons in the PC, bursting and nonbursting neurons. The nonbursting neurons receive olfactory inputs from the tentacles and transmit the outputs to the outside of the PC. On the other hand, the bursting neurons show spontaneous bursts, and suppress the activity of the nonbursting neurons. To examine whether the FMRFamidergic neurons are 